\title{
"In the Suitcase was a Boy": Representing Transnational Child Trafficking in Contemporary Crime Fiction
}

\author{
Charlotte Beyer
}

\begin{abstract}
This chapter investigates representations of transnational child trafficking in contemporary crime fiction, focusing specifically on the depiction of child trafficking and its victims. Beyer examines the role of crime fiction in raising reader awareness of human trafficking and of the child victims' predicament and plight, considering didactic dimensions of the genre and how it tends to erase victims in the aftermath of crime. Through detailed examinations of representations of child trafficking and its social and cultural contexts in selected post-2000 British and Scandinavian crime fiction texts, the chapter argues that crime fiction can be seen to engage explicitly in public and private debates around human trafficking, and, through its popular outreach, has the potential to affect popular perceptions of human trafficking and its victims.
\end{abstract}

Keywords Crime fiction $\bullet$ Educational $\bullet$ Gender $\bullet$ Narrative $\bullet$ Plot $\bullet$ Transnational child trafficking $\bullet$ Trauma $\bullet$ Violence

C. Beyer $(\bowtie)$

University of Gloucestershire, Cheltenham, UK

e-mail: cbeyer@glos.ac.uk

(C) The Author(s) 2018 


\section{Introduction: Exploring Representations of Child TRAFFICKING}

Since the agreement of the Palermo Protocol in 2000, there has been an increased interest in the topic of transnational human trafficking, particularly in in the news media, but also in documentary programmes and crime fiction (Gregoriou \& Ras, 2018; Dearey, 2018). ${ }^{1}$ This growing awareness of human trafficking has recently resulted in academic research into its representation. Notably, in 2016, the Anti-Trafficking Review journal devoted a special issue to the topic of "trafficking representations". However, while offering a number of articles examining the subject of the representation of human trafficking, the Anti-Trafficking Review issue included no examinations of crime fiction, or literary fiction. Similarly, scholarly investigations of transnational child trafficking representations are lacking, or considered together with adult female sex trafficking (Moore \& Goldberg, 2015). The neglect by critics of representations of child trafficking in contemporary crime fiction is puzzling because the genre offers thought-provoking and challenging depictions of different forms of child trafficking in a popular and generally accessible medium.

This chapter aims to redress this absence by offering a critical examination of representations of transnational child trafficking (TCT) in post2000 British and Scandinavian crime fiction novels. The representation of TCT in crime fiction (and literary fiction) has rarely received any sustained critical attention (with the notable exceptions of Moore and Goldberg (2015) and Bickford (2010, 2012). Importantly, therefore, this chapter offers a critical assessment of these representations and their wider cultural significance, by examining child trafficking narratives in selected crime fiction novels. Crime fiction enjoys a wide readership, and the representations generated by these books can potentially have a significant impact on public awareness of TCT. It is, therefore, pertinent to investigate portrayals of TCT in crime fiction, in order to analyse and understand these fictional representations and their effect, and to understand the social, cultural, and literary contexts for those representations. Through a critical analysis of depictions of TCT in crime fiction, this chapter identifies clichéd narrative patterns that frequently occur in crime fiction treating the subject of child trafficking, as well as tracing those representations that offer more complex and nuanced portrayals of TCT victims, their agency, resilience, and survival.

\footnotetext{
${ }^{1}$ The title quotation is from Kaaberbøl and Friis $(2008,2011$, p. 2).
} 


\section{Methodology and Context}

In this chapter I investigate representations of TCT in a selection of British and Scandinavian crime fiction novels: Marnie Riches' The Girl who Walked in the Shadows (2016), Ruth Dugdall's Nowhere Girl (2015), Lene Kaaberbøl and Agnete Friis' The Boy in the Suitcase (2008, 2011), Emelie Schepp's $(2014,2016)$ novel Marked for Life, and Minette Walters' The Cellar (2015). Additional references are made to other selected crime novels offering relevant representations of TCT, where appropriate to the discussion and to offer context. The above listed novels were selected for analysis due to the complex and nuanced representations of TCT they offer. TCT is a global phenomenon, and a number of novels from America and the Global South treat this subject, as well as the Western European texts selected for analysis here (Bickford, 2010; Moore \& Goldberg, 2015). For the purposes of this present investigation, concentrating on TCT as a theme in European crime fiction enables us to examine the (self-perceived) role of Europe as the destination (Jacomella, 2010, p. 4) for migrants, refugees, and trafficking victims, typically from the Global South but also from former Eastern Bloc countries, and to assess how literature and popular culture convey the important questions relating to human security and rights currently posed by human trafficking (Jonsson, 2009, p. 7).

In post-2000 crime fiction, representations of transnational sex trafficking (rather than forced labour), reflect prevailing media attitudes (Gregoriou \& Ras, 2018; Muždeka, 2018; Moore \& Goldberg, 2015). These stereotypes of sex trafficking of women can be observed in crime novels such as Stuart Neville, Stolen Souls (2011) and Stieg Larsson's The Girl Who Played with Fire $(2006,2009)$ among others, reflecting Ruivo's assertion that, "human trafficking continues to be largely associated with sexual exploitation" (2015, p. 22). However, the distinction between adult sex trafficking and child sex trafficking is at times erased, both in fiction and by critics referring to trafficked "women and girls" (Moore \& Goldberg, 2015). Matt Johnson's Deadly Game (2017) exemplifies a portrayal of female sex trafficking where the key female victim is a TCT victim, although this is not acknowledged in the novel. Deadly Game states on the opening page that the female victim was 17 when she was trafficked, thus underage according to the Palermo Protocol which states 18 as the age of consent and adulthood. ${ }^{2}$

\footnotetext{
${ }^{2}$ The Palermo Protocol defines child trafficking as the "recruitment, transportation, transfer, harbouring or receipt" of a child under the age of 18 for the purpose of exploitation; see Protocol (2000).
} 
This conflation of women and underage girls is problematic in considering representations of TCT, as it erases an important boundary regarding consent. The popular fixation with sex trafficking themes can also be seen in several other post-2000 crime fictions dealing with TCT plots, such as Liz Mistry's Unquiet Souls (2016) and Marnie Riches' The Girl who Walked in the Shadows. However, as the crime novels discussed in this chapter demonstrate, children are trafficked for a variety of purposes, as Fussey and Rawlinson also note: "Children are trafficked for diverse purposes, not only for commercial sexual exploitation, such as prostitution and pornography, but also servitude, forced labour, criminality, peonage and illicit military recruitment" (2017, p. 16; Bulman, 2017a). While acknowledging child sex trafficking representations, my chapter seeks to expand the investigation of TCT motifs, to include a range of other purposes, such as organ trafficking, child soldiering, modern slavery, and domestic slavery. This investigation of broader TCT themes assesses the impact of crime fiction authors depicting a range of non-sexual trafficking crimes, thus challenging a monolithic focus on sex trafficking.

TCT, the subject of my present investigation, requires particular attention, since as Pearce, Hynes, and Bovarnick state "the trafficking of children and young people [...] constitutes one of the most serious human rights violations of our time" $(2013$, p. 2). The seriousness of human trafficking is underlined by Ruivo, who describes it as an opportunistic crime exploiting the weak and powerless: "Traffickers and recruiters take advantage of the social and economic fragilities of countries, seeking their victims among those with financial difficulties in countries with high rates of unemployment and poverty, as well as lower levels of education" (2015, pp. 21-22). Yet the individuality and humanity of victims often appear to be erased through stereotypical representations of human trafficking (Gregoriou \& Ras, 2018). However, the importance of rendering trafficking victims visible is reflected in a 2017 feature in The Guardian. Under the title, "Traffickers take all that makes you human: faces of modern slavery", Kelly and Hodal's article (2017) uses photos of victims and their personal stories and experiences of human trafficking to make its point. The insistence on the humanity of trafficking victims is vital because it counters the move towards erasure and anonymisation of victims and their dignity otherwise seen in news media reportage on the subject (Gregoriou \& Ras, 2018). This chapter extends this preoccupation with the visibility of trafficking victims, specifically children, by using crime fiction novels to examine the politics of their representation. 
Employing a range of critical perspectives to examine themes in crime fiction of TCT, trauma, and victimhood specifically in relation to children, my chapter contributes to an emerging critical field. ${ }^{3}$ In investigating the selected crime novels and assessing the politics of representation, this chapter's methodology is focused around three areas: identification of types of TCT; crime fiction as a site for the representation of trauma and victimhood; and uses of crime fiction subgenres and/or narrative patterns. The purpose of this multi-faceted approach is to heighten understanding of the power of linguistic and fictional representation in creating complex representations of TCT, and to examine the role and function of crime fiction in shaping and influencing readers' understanding of TCT. The chapter draws on Fussey and Rawlinson's (2017) discussion of narrative patterns utilised to depict victimhood and agency in popular discourses around child trafficking. My analysis focuses specifically on thematic and discursive constructions of TCT victims, considering how conventional narrative patterns of heroism, abduction, and rescue are reflected, reproduced, or resisted in crime fiction novels, and to what effect. Fussey and Rawlinson refer to Propp's analysis of patterns of heroic rescue in folktales to illustrate how such motifs dominate representations of child victims in trafficking narratives $(2017$, p. 55$){ }^{4}$ The critique of stereotypical representations of trafficking victims and perpetrators by Kinney (2014), in her discussion of popular cultural texts and their depiction of human trafficking, has proved useful for analysing cultural responses to trafficking crimes. Other analyses of fictional portrayals of human trafficking include Moore and Goldberg (2015) and Bickford (2012). Cree, Clapton, and Smith examine representation of TCT and sexual exploitation in the twenty-first century, looking at the different kinds of exploitation children are subjected to and their countries of origin, concluding that stereotypical representations of TCT tend to depict the children as without agency (2014, p. 431). Such narrative patterns and positions are examined in the crime fictions analysed here, in order to assess whether portrayals of TCT offer stereotypical or alternative narratives and positions for victims, and how these representations may contribute to readers' and the wider public's knowledge of TCT.

\footnotetext{
${ }^{3}$ See also Bickford (2012) for an examination of the relationship between narrative and public perception of trafficking.

${ }^{4}$ Fussey and Rawlinson refer to Propp's Morphology of the Folktale (1968) [1928].
} 
My narrative analysis of the selected crime novels focuses specifically on the representation of child victims of trafficking, their experiences of trauma, and the literary language and techniques used to portray these experiences. This chapter draws on Bloom for an understanding of what constitutes trauma in children and how trauma manifests itself, and on Dodd and Vickroy for analyses of strategies used in literature to depict trauma. My investigation extends Dodd's argument that "[c]rime fiction opens up a space in which to depict more authentic and safe representations of traumatic experience to a willing and receptive audience" (2015, p. 5). The discussion of trauma and victimhood reflects Fussey and Rawlinson's insight that views of TCT are defined or shaped by "Western notions of innocence, guilt, childhood, and of the status of 'deserving' victim" (2017, p. 16). The narrative patterns, character portrayals, and detailed depictions of trauma in the selected novels are vital to their representation of TCT. I argue that these portrayals are integral to the genre's capacity to address the complexity of TCT to different audiences and readerships who are not necessarily knowledgeable about human trafficking, and to engender a sense of reader empathy for child victims of trafficking. As Bickford argues, "These novels can generate empathy and outrage, and they provide perspectives, information and analyses that can lead to a commitment to make change" $(2012$, p. 134). I argue that the depiction of child trauma plays a central role in conveying to the reader the suffering caused by TCT, and confronting them with the high individual and collective cost of this crime.

I draw on crime fiction criticism to underpin my identification of subgenres used in the crime novels under analysis. To that end, the crime fiction criticism by Worthington (2011) and Brunsdale (2016) provides genre-specific critiques of narrative elements and the use of subgenres in crime fiction. Crime fiction subgenres play an important part in drawing the reader's focus to a particular dimension of the novel, such as narrative perspective, psychological aspects, or the setting, thus framing and shaping TCT representations. This analysis considers the social critique articulated in these crime fictions, and the impact of the representations they offer on the reader's and general public's understanding of human trafficking, its causes, and its effects on victims. Brunsdale's (2016) examination of trafficking themes in Scandinavian crime fiction provides context for the Nordic Noir novels examined here. Worthington's (2011) and Bickford's $(2010,2012)$ analyses are useful in assessing the didactic dimensions of crime fiction, and reflecting on its capacity to affect readers' 
awareness of and engagement with significant public issues such as human trafficking. Crime fiction combines a narrative centred around generating suspense and mental problem-solving with realistic and affecting portrayals of crime and how crime impacts the individual and society, educating readers and the wider public about human trafficking. However, crime fiction novels may also struggle to reconcile a suspense-driven plot focused on entertainment with a realistic portrayal of TCT and its victims through the depiction of their trauma, and this is a question my chapter engages with. Through this multi-faceted critical approach blending crime fiction criticism with sociological and cultural analyses of human trafficking and theories about trauma and its representation, my analysis engenders a specific focus on the politics of representation and the capacity of crime fiction to create greater awareness of human trafficking, particularly TCT.

\section{Child Sex Trafficking}

Riches' The Girl who Walked in the Shadows $(2016)^{5}$ primarily portrays transnational child sex trafficking and child abduction, but also alludes to historical child sex trafficking crimes. Set in Britain, Germany, and Holland, Girl uses its British and European settings to represent complex contemporary Western European societies characterised by inequality, social tension, violence and brutality, and opportunistic crime. The novel's black female investigator character, Dr George McKenzie, is also an academic. ${ }^{6}$ George is a research fellow in Criminology at Cambridge University but also carries out work for the Home Office (Riches, 2016, Part 1, Chap. 4), and is asked to assist the Dutch police with profiling a murderer. This leads to George's involvement in the investigation of the disappearance of two young children, kidnapped from their parents' back garden. Their search uncovers a TCT ring where which acquires young children from Roma camps, who they then sell for sexual abuse, slave labour, and organ trafficking (Riches, 2016, Part 3, Chap. 45). Girl's trafficking plot is split into two separate storylines, a duality that reflects apparent contradictions in fictional representations of child trafficking based around perceptions of class and ethnicity. One plotline concerns the kidnapping of children from a socially privileged family. The other plotline concerns the organised

\footnotetext{
${ }^{5}$ From here on referred to as Girl.

${ }^{6}$ Riches' use of a BAME protagonist connects with her own background which she describes as "minority ethnic" (Diamond, 2016).
} 
transnational trafficking of a large number of children from Eastern Europe, primarily for sexual exploitation. Girl also depicts historic domestic child sex trafficking of children in the 1960s, 1970s and 1980s in Northern England, through George's research into the subject (Riches, 2016, Part 1, Chap. 2). ${ }^{7}$ These descriptions of historic and contemporary child sex trafficking in Europe, both transnational and domestic, reflect current media debates and their focus on sexual exploitation. ${ }^{8}$

The TCT plotline in Girl focuses primarily on the trafficking and exploitation of Roma children. The novel incorporates a discussion between George and another researcher, Sophie, about the trafficking of Roma children, explaining that the stereotypes and media representations surrounding the Roma, which hold them responsible for child abductions and trafficking, are far removed from the reality, which is that Roma children from south Eastern Europe are the most frequent victims of trafficking (Riches, 2016, Part 1, Chap. 9). Sophie explains to George that:

the kids trafficked out of Bulgaria, the Czech Republic, Hungary, Romania and Slovakia, Roma kids constitute about seventy per cent. They're disproportionately poor. Maybe someone trusted in the family or village offers to get a child work elsewhere. [...] movement of children over borders into brothels, sweatshops, begging on the streets. (Riches, 2016, Part 1, Chap. 9)

Explaining the context to Girl's portrayal of this subject, Fussey and Rawlinson state,

The Romani people [...] face a compounded victimisation: as collective 'collateral damage' of the economic and social insecurity that has accompanied neoliberal policies especially as exacerbated by the global economic crisis, and additionally as direct victims of the growing levels of poverty that have resulted from the crisis. $(2017$, p. 12)

Girl's representation of current debates around TCT, and its examination of stereotypes and misconceptions surrounding the Roma as both victims and perpetrators of crime, particularly trafficking, form an important part of the novel's attempt to raise reader awareness of TCT.

${ }^{7}$ These representations reflect media reports on domestic trafficking of vulnerable girls in northern England; see Perraudin (2016).

${ }^{8}$ For other portrayals of children transnationally trafficked for sexual abuse purposes, see Craig (2012) and Mistry (2016). 
Girl is mainly preoccupied with transnational child sex trafficking; however, the text gives a realistic depiction of TCT without sensationalising the sexual aspect, in contrast to some crime novels featuring TCT plotlines, such as Craig's Buckingham Palace Blues which seems to exaggerate the crime for shock effect, by having a young abused trafficked girl ask a police man "WWe fuck now?"” (Craig, 2012, p. 13). Girl is less sensationalist in its description of the traumatic effect on TCT victims of the sexual abuse they are subjected to (Riches, 2016, Part 1, Chap. 16). Riches' subtly harrowing portrayal of a distressed young, trafficked boy demonstrating to police the sexual abuse he was subjected to through the use of dolls, rather than through verbal evidence, reflects Bloom's recognition that "[s]ince a child's capacity for verbalization is just developing, their ability to put their traumatic experience into words is particularly difficult" $(1999$, p. 6). Through such descriptions, Girl demonstrates that language barriers for transnationally trafficked young children serve as an additional obstacle to adequately addressing and treating the victim's trauma. The novel draws a parallel between reports of TCT in the news media, and the reality encountered by its detective characters, describing one place where trafficked children are held as, "the basement of a semi-derelict Berlin townhouse where the stuff of nightmarish news reports was reality" (Riches, 2016, Part 3, Chap. 44). Alluding to media-demonised male paedophiles from Britain and Europe, Girl maintains the link established throughout the novel between masculinity, TCT and sexual abuse:

No Joseph Fritzl or Fred West had stood guard, yet this situation had seemed so far worse to Piet: missing children, at the mercy of not one psychopath but an entire network of traffickers and abusers that saw young lives only as commodities to be exploited and monetised. (Riches, 2016, Part 3, Chap. 44)

Breaking down the boundary between fiction and reality in its references to vilified and infamous real-life child abusers, Girl suggests not only that media reports shape public perceptions of human trafficking, but, somewhat problematically, that these representations are reflective of the reality of TCT.

Girl's complicated TCT plot reflects the point made by Conradi that " $\mathrm{t}]$ rafficking in children is abetted by a number of political, economic and social factors" $(2013$, p. 1211), outlining the complex factors that result in parents selling their children to traffickers, and individuals 
abducting children for personal gain $(2013$, p. 1211). In contrast, the novel's other child trafficking plot, the abduction of two children from an affluent family, draws on a less common form of child trafficking, according to Rogers (2012). The focus in Girl on young children as victims of child sex trafficking reflects the news media focus on youth (Gregoriou \& Ras, 2018), to some extent perpetuating established stereotypes about TCT, and echoing the idea of 'moral panic' in relation to TCT discussed by Cree et al. (2014). Through its use of British and European settings, the novel portrays TCT as an international crime involving organisations and gangs led by stereotypical ruthless and brutal traffickers (a feature also commented on by Moore \& Goldberg, 2015, p. 21). Girl reflects the point made by Fussey and Rawlinson that "trafficking of children for sexual exploitation is very much part of the 'headline space' occupied by sex trafficking" $(2017$, p. 45$)$. The novel occupies this "headline space" in its preoccupation with sex trafficking; however, its somewhat cluttered plotline prevents the reader from gaining a deeper, more nuanced understanding of child trafficking and the experiences of victims, or how to break the cycle of TCT.

\section{HARRAGA AND DOMESTIC NOIR}

Dugdall's Nowhere Girl (2015) uses the crime fiction subgenre of domestic noir ${ }^{9}$ to portray trafficking of girls and young females from the Global South by means of harraga to Western European homes for purposes of forced labour and sexual exploitation (Dunning, n.d.). Set in Luxemburg and Algeria, the novel also depicts the disappearance in Luxemburg of Ellie, a 16-year-old British girl, whose mother has arranged for her to be kidnapped at a funfair to teach her a lesson (Dugdall, 2015, p. 246), and the efforts by ex-probation officer Cate Atkins to find the girl. The novel is told through multiple narrative perspectives, including those of the trafficked girls. Nowhere Girl portrays the pervasiveness of child trafficking and the invisibility of modern slavery in everyday life, using the child kidnapping plotline alongside a depiction of TCT and modern slavery. Both plotlines explore the role of parents and families in child trafficking (May, 2016).

\footnotetext{
${ }^{9}$ Crouch (2013) on domestic noir: "it takes place primarily in homes and workplaces, concerns itself largely (but not exclusively) with the female experience [...] and takes as its base a broadly feminist view that the domestic sphere is a challenging and sometimes dangerous prospect for its inhabitants."
} 
Dugdall's portrayal reflects recent attention to human trafficking in Luxemburg. In a 2017 report, the President of the consulting commission on human rights called for greater awareness of the prevalence of human trafficking in the country, stating the country needs "awareness-raising about the types of human trafficking that exist among the wider public, hospital staff, social offices and teachers" (Bauldry, 2017).

The TCT plot in Nowhere Girl is based around the phenomenon of harraga, a term used to describe illegal immigrants from North Africa who have burned their personal documents in order to prevent identification by European authorities, "literally burn[ing] down social, cultural and familial identities" (Beneduce, 2008, p. 513; Abderrezak, 2016, p. 68). Dugdall's detailed depiction of the issue of harraga, and the social, cultural, and religious factors that give rise to it, makes the representation of human trafficking authentic and historically and culturally accurate. Her research into harraga goes beyond a superficial or sensationalised treatment and adds an important realistic dimension. Nowhere Girl portrays harraga through the depiction of the TCT of a young teenage girl, Amina, from her home in a poor Algerian village to Luxemburg. Through Amina's story, the reader learns about the cultural and religious problems that impact on families and communities in the Global South, leading to harraga. Amina's family is torn apart by religious conflict and patriarchal dominance, leading to her mother sending her daughter away to improve her life chances and to give her an education (Dugdall, 2015, pp. 26-27). ${ }^{10}$ Amina is trafficked by a local Algerian man called "Uncle Jak", who lives in Europe but returns to the village twice a year with his truck to take children away (i.e., to traffick them), under the auspices of offering them a better life (Dugdall, 2015, pp. 28-29). The novel describes the financial and human cost for the family of deciding to send Amina to Europe: "The cost of harraga had been great. Omi had sold the vineyard [...] It was their only asset, sold secretly and quickly" (Dugdall, 2015 , p. 79). The book also follows a 19-year-old woman called Jodie, who has also used harraga to travel to Europe with Amina, but who ends up being forced into prostitution. The novel's title, "Nowhere Girl", alludes to the invisibility of the trafficked girls from the police and authorities. Their existence without identity papers through harraga, enforced by

${ }^{10}$ Fox (2016) discusses the impact of religious intolerance, among a number of other factors, affecting what she calls "constructions of society and education." (pp. 57-58). See also Manian (2010). 
trafficking, reflects a social division between those who are visible, and those who are not, that is, those who are "nowhere". By exploring the TCT victim's experience through Amina's perspective, Nowhere Girl renders visible the emotional and physical trauma experienced by victims. The treatment of TCT in Dugdall is well-contextualised, and the novel makes an important contribution to knowledge for readers and researchers of crime fiction, in its examination of harraga, and its effects and implications.

Amina and Jodie's trafficking narratives draw on stereotypical modes of female exploitation, such as nail bar work and sexual abuse (Pearce et al., 2013, p. 31). ${ }^{11}$ Although both girls live together with an Algerian family in Luxemburg, descriptions of their living conditions clearly signal their slave status within the family. They are forbidden to go out, their sleeping arrangements are poor, the door to their dingy bedroom is locked from the outside, they are both given drugs every day (Dugdall, 2015, p. 138) and they are deprived of agency. ${ }^{12}$ Amina is made to work in a nail bar, whereas Jodie is exploited sexually (Dugdall, 2015, p. 159). Damaged by sexual exploitation, Jodie later breaks down and tells Amina:

They didn't bring us here to help us better ourselves. We are here to be used up, our beauty and our bodies [...] Harraga is a factory, and we girls are what it produces. But we are broken goods, and I am the first to break. When I am all used up, you will be next. (Dugdall, 2015, p. 227)

This critique of harraga and the illusion that it can lead to a better life, instead resulting in exploitation and slavery of trafficked females, is important in the novel's critical examination of TCT. Rather than offer freedom and opportunity in Europe, harraga seals the females' fate as powerless victims, "nowhere girls".

Nowhere Girl offers only a partial resolution of its trafficking plot. Whereas the novel provides rescue and a closure for the kidnapped white Western European Ellie, the two female trafficking victims from the Global South, Jodie and Amina, are abandoned in the plot with only a perfunctory rescue. The TCT victim, Amina, is left at a hospital in the care of the family that enslaved her, and Jodie is promised "a place to stay and an

\footnotetext{
${ }^{11}$ See also Craig (2012) and Mistry (2016) for representation of TCT for sexual exploitation purposes.

${ }^{12}$ See also Gangmasters (n.d.), "Spot the Signs".
} 
allowance" (Dugdall, 2015, p. 254). No further mention is made of how the authorities might assist them in their recovery from trauma, or whether they will be reunited with their families. Nor is there a sense of acknowledgement that Amina is a child and therefore extremely vulnerable, simply left with the family who have previously exploited her. Nowhere Girl reflects the failure of crime fiction to portray what happens "after"-the crime is solved and order is restored, but at the expense of the victim whose story fades into insignificance. This silence mirrors real-life TCT cases, as reported by Bulman who states that, in Britain, "child slavery victims are deprived of specialised support, pushing them back into abuse" (2017b).

\section{Organ Trafficking}

Danish authors Kaaberbøl and Friis' The Boy in the Suitcase $(2008,2011)^{13}$ focuses on various forms of TCT, including organ harvesting, illegal adoption, and sex trafficking. ${ }^{14}$ Boy depicts human trafficking as a social and cultural problem that affects individuals and families profoundly, and promotes a nuanced portrayal of TCT through a multiple character perspective. ${ }^{15}$ Set in Denmark, Lithuania, and Eastern Europe, the novel uses its organ trafficking plot to expose the exploitation of former Eastern Bloc countries and their resources by the West following the fall of the Berlin Wall (Stewart, 2016; see also Meyer, 2006). Boy follows Nina, the female investigator character and Red Cross nurse in a contemporary Danish society marked by social division, crime, and conflict. Through its quest motif and narrative structure, Boy creates a complex portrayal of TCT, reflecting how "a growing number of distinguished Danish crime novels are now exposing social issues like immigration-related tensions, drug usage, organized crime, human trafficking, and disruptions of family life, all symptoms of social disorder" (Brunsdale, 2016, "Denmark"). The problems in the Danish welfare society, including human trafficking, are explicitly referred to in the novel through Nina's response to the apathy of her fellow Danes: "if only she would let herself believe what no one else

\footnotetext{
${ }^{13}$ From here on referred to as Boy.

${ }^{14}$ See also McGilloway's (2013) representation of child trafficking for illegal adoption purposes.

${ }^{15}$ In Invisible Murder $(2010 ; 2012)$, Kaaberbøl and Friis treat the subject of the trafficking of dangerous substances and Roma adults and children.
} 
seemed to have any trouble believing: that Denmark was a safe haven for the broken human lives that washed up on its shores" (Kaaberbøl \& Friis, 2011 , p. 204). This social-realist critique engenders a compelling analysis of TCT but falls back on narrative patterns of heroic rescue and innocent victims which are often reproduced in TCT narratives, according to Fussey and Rawlinson (2017, p. 52).

Boy educates readers about the anguish and human suffering caused by TCT. This novel also features an abduction plot, alongside descriptions of other forms of exploitation such as female sex trafficking. Boy portrays a Lithuanian single mother Sigita, whose three-year-old son Mikas is taken from her at a playground. She later wakes up in hospital, having been drugged and beaten up by Mikas' kidnappers. Sigita traces Mikas to Denmark, by tracking down accomplices in the TCT ring, and travels there to reclaim her son. Meanwhile, Nina is given a key by an acquaintance to a locker at Copenhagen train station, where she finds Mikas alive inside a suitcase in the locker. The title of Boy alludes to the mode of transportation used in the novel for TCT, anticipating a TCT case from 2015, in which an eight-year-old boy from the Ivory Coast was trafficked to Spain inside a suitcase (Kassam, 2015). Boy's story follows her quest to discover the little boy's identity, while being hunted by Jucas, the trafficker who kidnapped Mikas, as well as Sigita. Jucas' mission is to bring the boy he has trafficked to a wealthy Danish couple whose adopted son is suffering from kidney failure and urgently needs a compatible transplant in exchange for a large sum of money. Mikas is compatible, because the sick boy is his older brother, illegally adopted at birth in Lithuania by the Danish couple when Sigita was only fifteen. Boy's organ trafficking plot thus revolves around a critique of the acquisition of organs for the privileged wealthy in Western Europe through criminal means such as TCT from former Eastern Bloc countries such as Lithuania (Stewart, 2016).

Mikas' mother Sigita is the focus in the narrative for an exploration of maternal affect and the mother without her child (Hansen, 1997). ${ }^{16}$ The novel's inclusion of the portrayal of a mother whose child has been trafficked, allows for an examination of an area of trafficking commonly absent from debates and representations around this crime-namely maternal experience. Boy's representation of the mother's abjection

\footnotetext{
${ }^{16}$ Dugdall's Nowhere Girl also includes maternal perspectives in its trafficking narrative, in the form of confessional-tone letters written to Ellie, the kidnapped daughter from Bridget, the guilt-ridden mother who arranged it.
} 
encourages the reader to empathise with the mother and her loss and confront the trafficked child's trauma. ${ }^{17}$ Including these important yet frequently omitted dimensions contributes to Boy's nuanced representation of TCT. Boy describes Mikas' traumatised behaviour, screaming uncontrollably and urinating on the floor with fear (Kaaberbøl \& Friis, 2011, pp. 225-257), reflecting what Bloom calls "engraving of trauma": "When we are overwhelmed with fear, we lose the capacity for speech, we lose the capacity to put words to our experience" $(1999$, p. 5). This depiction and other portrayals in the novel of Mikas give the reader an insight into the harmful effects of trauma on trafficked children, through Boy's realistic portrayals of traumatised behaviours and responses. ${ }^{18}$ The significance of this type of depiction is highlighted by Vickroy who commends, "the capacity of trauma in literature to engage the reader's empathy by closely examining the personal and community contexts of trauma and its psychological ramifications" (2014, p. 148). As part of the novel's complex representation of TCT, the reader also learns about Jucas, the novel's brutal trafficker whose character reflects the stereotypically thuggish trafficking villain described by Moore and Goldberg (2015, p. 21). Having been sexually abused in an orphanage (Kaaberbøl \& Friis, 2011, p. 265), Jucas, in turn, brutalises others, as his reflections on torturing his victims reveal (Kaaberbøl \& Friis, 2011, p. 157). Jucas' view of Mikas that, "the kid was currency" (Kaaberbøl \& Friis, 2011, p. 208) further demonstrates how children are objectified and commodified through TCT trafficking.

Boy depicts how Nina is affected in her personal and professional life by her demanding and often harrowing work with refugees and human trafficking victims. Her reflections on the difficulties of her work serve the purpose of educating the reader regarding human trafficking, as she considers TCT, and the brutality of the people behind it, as well as the indifference of the general population: "the real beauty of it all for the cynical exploiters was that ordinary people didn't care" (Kaaberbøl \& Friis, p. 213). Nina's work gives her an awareness of the ways in which children are exploited and abused, such as children forced by traffickers to beg and steal, sold by parents, instructed to escape from refugee centres and authorities (Kaaberbøl \& Friis, 2011, p. 214). Like Girl and Nowhere Girl, Boy portrays the impact of social inequality on individual victims

\footnotetext{
${ }^{17}$ See Hansen's (1997) examination of maternal loss of children.

${ }^{18}$ See Rafferty (2008) on the emotional and psychological damage caused to trafficked children.
} 
vulnerable to opportunistic crime, but also shows how traffickers may themselves be impacted on by these environments and acting out of economic necessity. Boy's quest-driven rescue narrative resolves its TCT plot by returning Mikas to his mother; however, both Sigita and Mikas are dropped from the story following his return. Boy's quest narrative is constructed around central questions of identity and belonging: the quest to discover the identity of the little boy and to keep him safe from traffickers, to reunite him with his mother and return him to where he belongs. These are narrative resolutions with which readers can identify emotionally; but although this affective dimension is important, it cannot mask the gap in Boy's trafficking narrative: the question of what happens to the TCT victim and his family after the rescue and what support (if any) they receive.

\section{Child Soldiers ANd Victims}

Swedish author Schepp's (2016) novel Marked for Life ${ }^{19}$ uses crime fiction subgenres, such as the psychological novel and the police procedural, ${ }^{20}$ to investigate the issue of child soldiers: children who have been trafficked transnationally and forcibly trained to fight, often being exposed to, and suffering the effects from, extreme violence (Child Recruitment and Use, n.d.). The theme of child soldiering is unusual in crime fiction, and Schepp's treatment of the theme makes her novel stand out from the other crime texts discussed earlier, and their predominant focus on child sex trafficking or individual child abductions. Commenting on child soldiering, Tiefenbrun states that: "The use and abduction of child soldiers is an international crime and a heinous human rights violation that is caught in the intersection of four different but related areas of the law: children's rights, slavery, human trafficking, and exploitative child labor" (2007, p. 434). Child soldiers tend to be recruited in areas of armed conflict involving warlords, such as Africa and Asia (Mapp, 2010, p. 72); however, Schepp's novel transposes this particular TCT crime into a Swedish setting

\footnotetext{
${ }^{19}$ From here on referred to as Marked.

${ }^{20}$ The psychological crime novel focuses on inner dimensions, exploring the thoughts and reflections of characters, including experiences of, and responses to, trauma. The police procedural depicts the workings of a police force in their crime solving efforts, focusing on individual police characters as well as on their team work. See also Worthington (2011).
} 
in order to examine its devastating effect on individuals, families, and communities.

Set in Sweden, Marked opens with the murder of the head of the migration board, an event that forces together the two main threads in the narrative, namely the use of child soldiers and the female protagonist, public prosecutor Jana Berzelius. It transpires during the police investigation that the aforementioned murder was committed by a child soldier who is later found dead. Marked uses the interspersed harrowing flashbacks of a young girl who is being trafficked from Chile with her parents inside a container alongside a number of other families, having been promised a bright future in Europe (Schepp, 2016, p. 22). However, the girl's graphic memories of the scene reveal that all the adults in the container are killed on arrival by the traffickers, and the children taken away, beaten, drugged, and forcibly trained to become child soldiers. The girl is renamed Ker by the traffickers as part of a brutal training regime which involves getting her addicted to drugs and forcing her to fight the other children to the death. Making child soldiers dependent on hard drugs is a strategy for control, as Tiefenbrun points out (2007, p. 478). The trafficker, whom Ker only knows as "the man with the scar", carves the children's soldier names into their necks, to establish their new identities which he controls (Schepp, 2016 , p. 89). Only later does the reader make the connection between Jana and Ker, the girl who has been trafficked and is being exploited as a child soldier, through the description of the characteristic scar on Jana's neck, a strategy which also assists the reader in understanding Jana's trauma. Jana's recurring nightmares and violent responses reflect Vickroy's assertion that "[f]iction that depicts trauma incorporates varied responses and survival behaviours within the characterization of survivors" (2014, p. 130). Through the character of Jana/Ker, Marked engenders the reader's engagement with the trauma suffered by trafficked child soldiers and reconsideration of their assumptions about children and innocence (see also Fussey \& Rawlinson, 2017).

Through her realist portrayal, Schepp calls attention to the brutal strategies used to transform a child into a slave and a soldier, themes which she states are common to Nordic Noir (Zander, 2016). As in Boy, Schepp's focus on TCT reflects a trend in Scandinavian crime fiction to investigate controversial topics, reflecting a critical awareness of social and cultural failings such as "crime and terrorism; domestic violence; drug and alcohol abuse; human trafficking; local and international gang activity" (Brunsdale, 2016, "Introduction"). Schepp has spoken in a "Shots: Crime and Thriller 
Ezine" feature about human trafficking and child soldiering, stating that "this actually happens in Sweden today [...] Adults and children disappear, are kidnapped, are taken away and are forced into a life of prostitution or slavery. Human traffickers profit on people in peril" (Schepp, n.d.). Child soldiering has been associated mainly with African and Middle Eastern countries in recent decades (Mapp, 2010, p. 69); however, Schepp's use of this form of human trafficking in a Swedish context raises reader awareness and draws attention to the global impact of child soldiering.

By depicting the brutalisation of Jana/Ker during her combat training, and the life-long damaging impact on her as an adult, Marked examines the emotional and psychological trauma experienced by child soldiers. These problems are also discussed by Tiefenbrun who states that child soldiers "feel guilty because they have survived [...] The children have lost their autonomy and self-control" $(2007$, p. 478). As an adult, Jana remains haunted by memories and sounds which return to torment her in her dreams. She wants to unlock the trauma but cannot find the key:

She had experienced the same dream for as long as she could remember. It was always the same images. It irritated her that she didn't understand what the dream meant. She had turned, twisted and analyzed all the symbols each time she fell victim to it. (Schepp, 2016, p. 46)

These descriptions echo Vickroy's explanation of the strategies used in fiction to represent traumatised individuals: "Through familiar literary elements trauma fiction creates constructs of that experience with prototypically imagined situations and symptoms, metaphoric dreams, death imagery, and narrative styles that mimic such experience, for example, fragmented thoughts, dissociative outlook, de-contextualized visualization, etc." $(2014$, p. 138) When Jana sees a dead boy (a child soldier) bearing evidence of brutal physical abuse, with a name carved into his neck similar to hers, her recognition of the sign and extreme reaction reflect the severity of the trauma she has suffered, "the ground began to rock beneath her feet. She gripped the edge of the table with both hands so as not to fall" (Schepp, 2016, p. 135). This and other descriptions of Jana's trauma allow the reader to understand the affective impact of TCT and to recognise it as a crime against the individual child. At the end of the novel, Jana confronts Papa, the man with the scar who trafficked her and brutalised her. In a bid to maintain his control over her, he tells her that she was just an "illegal kid", "meaningless" (Schepp, 2016, p. 359), and explains that 
"In many countries there are young people who are deliberately recruited, trained and used in armed forces. I do the same here" (Schepp, 2016, pp. 361-362). Although the novel does not bring a resolution for Jana, it illustrates in graphic ways the horrors of child soldiering, and the ruthlessness of those involved in TCT, but also the incredible resilience and courage of children who have survived severe trauma.

Walters' The Cellar (2015) specifically uses the trafficked child's perspective to explore the harrowing effects of TCT, forced labour, and sexual abuse, and the violent feelings and responses this abuse may generate in the victim. In Walters' novel, the female protagonist Muna has been fraudulently obtained from a Nigerian orphanage at age 8 by the Songolis, an African family who then trafficked her to Britain. Here, they keep her as a domestic slave, locked away, subjected to physical punishment and beatings, and sexual abuse by the father of the family. The dark cellar, in which she is imprisoned at night, also the site of her sexual abuse, becomes a symbolic space marking the invisibility and silence of the trafficking victim. ${ }^{21}$ The novel depicts how Muna, now aged 14 , starts avenging herself on the Songoli family, whose members disappear one by one. The Cellar problematises the focus in the conventional trafficking narrative on rescue, in its rejection of a happy ending and restoration of normality for the child victim. Instead, Walters' represents TCT as an invisible scourge that undermines the family unit and haunts affluent Western societies. The Cellar uses the motif of captivity as a central motif, with the cellar itself as a symbol of that captivity and the trauma inflicted through TCT. Drawing on the psychological thriller and domestic noir, The Cellar places the patriarchal family at the heart of its TCT portrayal, interrogating its damaging power dynamics and resulting taboo feelings of rage in the child victim. This novel provides a clear example of how, as Vickroy states, "[f]iction provides readers with a wealth of thick description of the conditions and characteristics of traumatic experience" (2014, p. 137). Muna's rage transforms the cellar, from a space where she was abused, to the locus for her deadly revenge. However, her rage is also symptomatic of a traumatised child's cry for help, echoing Caruth's assertion regarding trauma that: "It is this plea by an other who is asking to be seen and heard, this call by which the other commands us to awaken" (1996, p. 9). As in Marked, these compelling but appalling representations of trafficked girls,

${ }^{21}$ This text is discussed in more detail in Gregoriou and Beyer, 2019. 
their rage and capacity for extreme violence illustrate with perhaps the greatest clarity the devastation caused by trafficking. Even in crime fiction, a genre driven by representations of violence and transgression, these shocking portrayals make for difficult reading.

Works like those by Schepp, Walters, and Dugdall appear to be the exception in the growing body of popular literature portraying human trafficking, in their sustained narrative focus on the trafficked child's experience and trauma. In crime fiction generally, victims are seldom given the main voice and narrative perspective, and this silence or absence contributes to the stereotypical construction of victimhood as devoid of agency. Such narrative erasure extends to representations of human trafficking and its victims, where specifically children's perspectives tend to be absent from fictional depictions of this crime. However, in the novels by Schepp, Walters, and Dugdall, it is the victims' characters and stories that are the most compelling and emotionally engaging aspects of the crime plot. Their TCT narratives are not determined by ideas of innocence or rescue, but instead by individual self-preservation and courage. By foregrounding TCT characters within the narratives and giving these victims presence and agency within the stories, these novels contribute to producing a more nuanced picture of trafficking and victimhood, one which seeks to challenge stereotypes, but also conveys the victim's feelings of violence, desire for revenge, and hatred.

\section{Conclusion: The Politics of Representing TCT in Crime Fiction}

The representation in crime fiction of TCT, the child victims and their families, has rarely received critical attention as a subject in its own right. This oversight detracts from the way in which literature contributes to current debates around the relationship between Western Europe, the former Eastern Bloc and the Global South, which are played out in human trafficking narratives. However, as we have seen, crime fiction novels feature complex storylines about TCT, some of which present child victims at the centre of the narrative. Using a range of thematic and textual means, the texts examined in this chapter explore the cultural narratives that dominate how readers perceive children, and the foundational texts with their patterns of heroic rescue which tend to dominate their portrayal, and contribute to affecting and shaping contemporary cultural, social, and political responses to TCT (Fussey \& Rawlinson, 2017, p. 55). These 
crime novels here thus implicitly or explicitly engage in public and private debates around human trafficking (Dugdall; Kaaberbøl \& Friis; Schepp; Walters), and contribute vitally to a wider understanding of academic research into human trafficking (Riches) (see also Bickford, 2012). Through its popular outreach, crime fiction thus has the potential to affect popular perceptions of human trafficking.

Assessing the gender political dimensions of the TCT portrayal in the novels examined, we have seen that certain stereotypes prevail, and that these are particularly pronounced in the portrayal of traffickers. Human traffickers tended to be male, particularly when their actions were associated with violence and brutality, whereas females typically played an accomplice role, but were rarely in charge of trafficking operations (Riches; Dugdall; Kaaberbøl \& Friis; Schepp). This conventional gender role distribution can also be observed in representations of trafficking victims in popular culture which concentrate on female sex trafficking, thereby "oversimplify[ing] dynamics of trafficking and global migration, [and] recreat[ing] damaging stereotypes about victims" (Kinney, 2014, p. 104). In the novels examined here, the child victims portrayed are of both genders, suggesting that where TCT depiction in crime fiction is concerned, gender roles are less stereotypically conceived than in media reportage, for example, which tends to focus on adult (although young) female victims of sex trafficking (Gregoriou \& Ras, 2018). Likewise, the theme of the family features prominently in the plot of several of these crime fictions, reflecting a preoccupation with the theme of identity, but also drawing attention to the complex role family plays in TCT. Cree et al. argue that, "contemporary trafficking stories highlight the uncaring parents who sell children into servitude and the cruel 'people traffickers' who exploit them financially and sexually" (2014, p. 431). The crime fictions discussed here problematise the role and agency of parents in TCT, especially Dugdall; Kaaberbøl and Friis, raising questions surrounding responsibility and neglect which are key to constructions of gender and parenting (see also Moore \& Goldberg, 2015, pp. 22-23).

The narrative patterns and moral themes utilised in crime fiction highlight the already heightened and exaggerated stereotypes often at play in cultural and media representations of human trafficking. These stereotypes frequently form part of the TCT narrative which, according to Cree et al., is often construed as:

a morality tale of 'goodies' (the innocent child victims) [...], 'baddies' (the cruel perpetrators, often portrayed as 'foreigners') and 'saviours' (the police 
officers, social workers, politicians, and NGO workers who bring this issue to the public's attention and 'save' children from harm. (Cree et al., 2014, p. 429, also cited in Fussey and Rawlinson, 2017, p. 54)

According to Fussey and Rawlinson, such narratives result in TCT crimes "occup[ying] headlines and print space" $(2017$, p. 54), which, however, do not result in "prosecutions and criminal justice interventions" (2016, p. 45). As stereotypical representations of trafficked children are perpetuated through the dominant narrative of rescue which reinforce trafficking clichés, these representations do not address the cycle of trafficking or fundamentally change how victims are seen. Crime fiction texts rarely tell the story of what happens to victims after the rescue. This erasure from trafficking narratives of the aftermath of crime and the victim's experience extends to real life, too, as Bulman explains: "Victims of slavery and human trafficking 'abandoned' as soon as they are identified. Trafficked victims who escape sexual exploitation and domestic servitude face 'sharp cliff edge' as no provisions are systematically put in place to assist their recovery" (2017a; Bokhari, 2008). However, in terms of narrative function, the crime fictions examined here attempt at least a partial restoration of order and justice for victims, a central purpose of the genre. Along with suspense and problem-solving, these are narrative elements that appeal to readers and enable them to cope with the otherwise bleak representations of violence and harm in TCT.

This chapter has argued that crime fiction has the capacity to put a human face to TCT, through nuanced portrayals created through political use of literary language and form, thus underlining the significance of literary representation. As Nestingen states, contemporary crime fiction presents "stories [that] use crime to engage with debates over individualism, collective claims, and the status of national homogeneity, gender, and transnational relations" (2008, p. 14). Ruivo reminds us that trafficking victims are already marginalised or disregarded within their societies, because of their gender, age, social status, and lack of authority (2015, p. 22). The power and influence of representation is undeniable, as Andrijasevic and Mai (2016) state, particularly when it comes to "understanding the historical, cultural and political specificity of the figure of the [trafficking] victim". Crime fiction authors are responding to the pressing call for more authentic representations of TCT, a call echoed by Gregoriou and Ras (2018) in relation to media representations of human trafficking, and for more efforts to be made in order to support victims. Through its 
compelling representations and insistence on their presence, crime fiction plays an significant role in negating the invisibility and abandonment of TCT victims.

\section{REFERENCES}

Abderrezak, H. (2016). Ex-centric migrations: Europe and the Maghreb in Mediterranean cinema, literature, and music. Indiana: Indiana University Press.

Andrijasevic, R., \& Mai, N. (2016). Editorial: Trafficking (in) representations: Understanding the recurring appeal of victimhood and slavery in neoliberal times. Anti-Trafficking Review, (7). Retrieved December 8, 2017, from http://www.antitraffickingreview.org/index.php/atrjournal/issue/view/15

Bauldry, J. (2017, March 16). Lux. Is failing human trafficking victims. Delano. Retrieved November 9, 2017, from http://delano.lu/d/detail/ news/lux-failing-human-trafficking-victims/139863

Beneduce, R. (2008). Undocumented bodies, burned identities: Refugees, sans papiers, harraga when things fall apart. Social Science Information, 47(4), 505-527.

Bickford, D. M. (2010). Novels, public policy and anti-trafficking efforts. In Second Annual Interdisciplinary Conference on Human Trafficking, 2010. Paper 5, pp. 1-7. Retrieved December 13, 2017, from http://digitalcommons.unl.edu/ humtrafconf $2 / 5$

Bickford, D. M. (2012). "We all like to think we've saved somebody": Sex trafficking in literature. Journal of International Women's Studies, 13(3), 127-136.

Bloom, S. L. (1999) "Trauma theory abbreviated." from The final action plan: A coordinated community-based response to family violence. Attorney General Mike Fisher's Task Force on Family Violence. Retrieved November 9, 2017, from http://sanctuaryweb.com/

Bokhari, F. (2008). Falling through the gaps: Safeguarding children trafficked into the UK. Children and Society, 22, 201-211.

Brunsdale, M. M. (2016). Encyclopedia of Nordic crime fiction: Works and authors of Denmark, Finland, Norway and Sweden since 1967. Jefferson: McFarland. Kindle.

Bulman, M. (2017a, May 21). Victims of slavery and human trafficking "abandoned" as soon as they are identified. The Independent. Retrieved September 28, 2017, from http://www.independent.co.uk/news/uk/home-news/ human-trafficking-slavery-a7743816.html

Bulman, M. (2017b, October 13). Government urged to overhaul slavery policy as child victims slip back into exploitation after being rescued. The Independent. 
Retrieved November 9, 2017, from http://www.independent.co.uk/news/ uk/home-news/slavery-policy-child-victims-national-referral-mechanismgovernment-overhaul-exploitation-a7998656.html

Caruth, C. (1996). Unclaimed experience: Trauma, narrative and history. Baltimore, MD: Johns Hopkins University Press.

Child Recruitment and Use. (n.d.). Office of the special representative of the general secretary for children and armed conflict. United Nations. Retrieved November 9, 2017, from https://childrenandarmedconflict.un.org/effectsof-conflict/six-grave-violations/child-soldiers/

Craig, J. (2012). Buckingham Palace blues. London: Robinson. Kindle.

Cree, V. E., Clapton, G., \& Smith, M. (2014). The presentation of child trafficking in the UK: An old and new moral panic? British Journal of Social Work, $44(2), 418-433$.

Crouch, J. (2013). Genre bender. Blog. Retrieved December 17, 2017, from http://juliacrouch.co.uk/blog/genre-bender

Dearey, M. (2018). Who are the traffickers? A cultural criminological analysis of traffickers as represented in the $\mathrm{Al}$ Jazeera documentary series Modern Slavery: A Twenty-First Century Evil. In C. Gregoriou (Ed.), Representations of transnational human trafficking: Present-day news media, true crime, and fiction. Basingstoke: Palgrave.

Diamond, K. (2016, November 30). Marnie Riches and Katarina Diamond in conversation. The Crime Readers' Association. Retrieved September 28, 2017, from https://thecra.co.uk/marnie-riches-katerina-diamond-conversation/

Dodd, L. (2015). The crime novel as trauma fiction. Minding the gap: Writing across thresholds and fault lines papers. In The refereed proceedings of the 19th conference of the Australasian Association of Writing Programs, 2014, Wellington NZ. Retrieved November 9, 2017, from http://www.aawp.org.au/publications/minding-the-gap-writing-across-thresholds-and-fault-lines/

Dugdall, R. (2015). Nowhere girl. London: Legend Press.

Dunning, M. E. (n.d.). Nowhere girl by Ruth Dugdall. Mari Illis Dunning. Retrieved November 9, 2017, from https://mariellisdunning.cymru/bookreviews/nowhere-girl-by-ruth-dugdall/

Fox, C. (2016). Who is my neighbour? Unleashing our postcolonial consciousness. The International Education Journal: Comparative Perspectives, 15(3), 57-76.

Fussey, P., \& Rawlinson, P. (2017). Child trafficking in the EU: Policing and protecting Europe's most vulnerable. Abingdon: Routledge.

Gangmasters \& Labour Abuse Authority. (n.d.). Spot the signs. Retrieved November 9, 2017, from http://www.gla.gov.uk/who-we-are/modern-slavery/who-we-are-modern-slavery-spot-the-signs/

Gregoriou, C., \& Beyer, C. (under consideration 2019). The transnational human trafficking victim in Minette Walters' The Cellar: A critical and stylistic analysis of the complexity of victim representation in crime fiction. In U. Tabbert \& 
J. Douthwaite (Eds.), The linguistics of crime. Cambridge: Cambridge University Press.

Gregoriou, C., \& Ras, I. A. (2018). "Call for purge on the people traffickers": An investigation into British newspapers' representation of transnational human trafficking, 2000-2016. In C. Gregoriou (Ed.), Representations of transnational human trafficking: Present-day news media, true crime, and fiction. Basingstoke: Palgrave.

Hansen, E. T. (1997). Mother without child: Contemporary fiction and the crisis of motherhood. University of California Press.

Jacomella, C. (2010). Media and migrations: Press narrative and country politics in three European countries. Reuters Institute Fellowship Paper. Oxford: Oxford University. pp. 1-102. Retrieved December 19, 2017, from http://reutersinstitute. politics.ox.ac.uk/sites/default/files/research/files/Media\%2520and\%2520migr ations $\% 2520$ Press $\% 2520$ narrative $\% 2520$ and $\% 2520$ country $\% 2520$ politics $\% 2520$ in\%2520three\%2520European\%2520countries.pdf

Johnson, M. (2017). Deadly game. London: Orenda Books.

Jonsson, A. (2009). Introduction: Human trafficking and human security in the Baltic Sea region. In A. Jonsson (Ed.), Human trafficking and human security (pp. 1-9). Abingdon: Routledge.

Kaaberbøl, L., \& Friis, A. (2008, 2011 Eng.transl.). The boy in the suitcase. New York: Soho. Kindle.

Kaaberbøl, L., \& Friis, A. (2010, 2012 Eng.transl.). Invisible murder. New York: Soho. Kindle.

Kassam, A. (2015, May 8). X-ray scan at Spanish border finds child stashed inside suitcase. The Guardian. Retrieved November 9, 2017, from https://www. theguardian.com/world/2015/may/08/x-ray-scan-at-spanish-border-findschild-stashed-inside-suitcase

Kelly, A., \& Hodal, K. (2017, July 30). "Traffickers take all that makes you human": Faces of modern slavery-In pictures. The Guardian. Retrieved December 13, 2017, from https://www.theguardian.com/global-development/gallery/2017/jul/30/traffickers-take-all-makes-you-human-facesmodern-slavery-in-pictures

Kinney, E. (2014). Victims, villains, and valiant rescuers: Unpacking sociolegal constructions of human trafficking and crimmigration in popular culture. In M. J. Guia (Ed.), The illegal business of human trafficking (pp. 87-108) Cham: Springer.

Larsson, S. (2006, 2009). The girl who played with fire. London: MacLehose Press. Manian, S. (2010). The wretched of the earth: Trafficking, the Maghreb, and Europe. In K. A. McCabe \& S. Manian (Eds.), Sex trafficking: A global perspective (pp. 83-90). Plymouth: Lexington Books.

Mapp, S. C. (2010). Global child welfare and well-being. Oxford: University of Oxford Press. 
May, R. (2016, May 28). 'Nowhere girl' by Ruth Dugdall. Promoting crime fiction by Lizzie Hayes. Retrieved November 9, 2017, from http://promotingcrime.blogspot.co.uk/2016/05/nowhere-girl-by-ruth-dugdall.html

McGilloway, B. (2013). The stolen child. London: Pan. Kindle.

Meyer, S. (2006). Trafficking in human organs in Europe: A myth or an actual threat? European Journal of Crime, Criminal Law and Criminal Justice, 14(2), 208-229.

Mistry, L. (2016). Unquiet souls. [Place of publication not identified]: Bloodhound Books.

Moore, A. S., \& Goldberg, E. S. (2015). Victims, perpetrators and the limits of human rights discourse in post-Palermo fiction about sex trafficking. The International Journal of Human Rights, 19(1), 16-31.

Muždeka, N. (2018). Not all human trafficking is created equal: Transnational human trafficking in the UK and Serbian news media texts-Narratological and media studies approaches. In C. Gregoriou (Ed.), Representations of transnational human trafficking: Present-day news media, true crime, and fiction. Basingstoke: Palgrave.

Nestingen, A. (2008). Crime and fantasy in Scandinavia: Fiction, film and social change. Seattle: University of Washington Press.

Neville, S. (2011). Stolen souls. London: Harvell Secker.

Pearce, J. J., Hynes, P., \& Bovarnick, S. (2013). Trafficked young people: Breaking the wall of silence. London: Routledge.

Perraudin, F. (2016, April 8). Rochdale grooming case: Nine men jailed for up to 25 years each. The Guardian. Retrieved December 15, 2017, from https:// www.theguardian.com/uk-news/2016/apr/08/rochdale-grooming-case10-men-sentenced-to-up-to-25-years-in-jail

Protocol to Prevent, Suppress and Punish Trafficking in Persons Especially Women and Children, supplementing the United Nations Convention against Transnational Organized Crime. (2000). United Nations Human Rights. Retrieved November 9, 2017, from http://www.ohchr.org/EN/ ProfessionalInterest/Pages/ProtocolTraffickingInPersons.aspx

Rafferty, Y. (2008). The impact of trafficking on children: Psychological and social policy perspectives. Child Development Perspectives, 2(1), 13-18.

Riches, M. (2016). The girl who walked in the shadows. London: Harper Collins. Kindle.

Rogers, S. (2012, October 4). Child abduction in England \& Wales: The key numbers. The Guardian. Retrieved December 14, 2017, from https://www. theguardian.com/news/datablog/2012/oct/04/child-abduction-statisticsengland-wales

Ruivo, J. (2015). The fragilities of human trafficking victims. In M. J. Guia (Ed.), The illegal business of human trafficking (pp. 21-28). Cham: Springer.

Schepp, E. (2014; 2016). Marked for life. London: HQ. Kindle. 
Schepp, E. (n.d.). The inspiration behind marked for life. Shots: Crime \& Thriller Ezine. Retrieved November 9, 2017, from http://www.shotsmag.co.uk/ feature_view.aspx? FEATURE_ID=344

Stewart, F. (2016). Der Frauenkrimi: Women's crime writing in German. In K. Hall (Ed.), Crime fiction in German: Der Krimi (European crime fictions). Cardiff: University of Wales Press. Kindle (Chapter 6).

Tiefenbrun, S. (2007). Child soldiers, slavery and the trafficking of children. Fordham International Law Journal, 31(2), 415-486.

Vickroy, L. (2014). Voices of survivors in contemporary fiction. In M. Balaev (Ed.), Contemporary approaches in literary trauma theory (pp. 130-151). London: Palgrave Macmillan.

Walters, M. (2015). The cellar. London: Harper Collins.

Worthington, H. (2011). Key concepts in crime fiction. Houndmills: Palgrave.

Zander, J. (2016, June 21). Nordic Noir is a reflection of modern Europe: Emelie Schepp \& Joakim Zander discuss Scandinavian crime fiction as a mirror for evolving European societies. Electric Lit. Retrieved November 9, 2017, from https://electricliterature.com/nordic-noir-is-a-reflection-of-modern-europe1508a07a5398

Open Access This chapter is licensed under the terms of the Creative Commons Attribution 4.0 International License (http://creativecommons.org/licenses/ by $/ 4.0 /$ ), which permits use, sharing, adaptation, distribution and reproduction in any medium or format, as long as you give appropriate credit to the original author(s) and the source, provide a link to the Creative Commons license and indicate if changes were made.

The images or other third party material in this chapter are included in the chapter's Creative Commons license, unless indicated otherwise in a credit line to the material. If material is not included in the chapter's Creative Commons license and your intended use is not permitted by statutory regulation or exceeds the permitted use, you will need to obtain permission directly from the copyright holder.

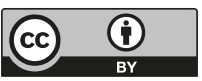

